\section{A aposentadoria especial dos professores}

\section{Valdacyr S. Scomazzon}

Procurador do Estado e Professor da UFRGS, aposentado;

Ex-Professor da PUCRGS e da Escola Superior da Magistratura. Advogado.

\section{Abstract}

The purpose of this article is formulating a critical view both of the restrictive exegesis adop ted by the Public Administration of Rio Grande do Sul, regarding the 40th article, item III, $b$, of the Federal Constitution, and, also, of the provisions contained in Law RS nbr. 9.481/93, which, making an extensive interpretation of the constitucional precept, enumerates several activities as "teaching functions", an expression of the Constitution which gave rise to much controver sy about its reach.

This paper, basically, proposes a less radical exegesis of the constitutional precept referred, departing from the two extreme positions mentioned before.

A vigente Constituição Federal estatui, em seu art. 40, item III, alínea $b$, que

"O servidor será aposentado:

III - voluntariamente:

b) aos trinta anos de efetivo exercício em funfões de magistério, se professor, e vinte cinco, se professora, com proventos integrais;" (grifei)

Disposição idêntica abrigava a anterior Lei Maior (1967/69), em seu artigo 101, III, combinado com o artigo $165, \mathrm{XX}$, verbis: do:

"Art. 101 - O funcionário será aposenta-

III - voluntariamente, após trinta e cinco anos de serviço, ressalvado o disposto no art. 165, item XX." (Item com redação determinada pela Emenda Constitucional $n^{\circ}$ 18 , de 30-6-81) lhoria de sua condição social: va quanto na judicial. entre outras coisas: vida à nobre tarefa de servir.

legre, 10: 190-204, jul. 1994 trabalhadores os seguintes direitos, além de outros que, nos termos da lei, visem à me-

XX - a aposentadoria para o professor após trinta anos e, para a professora, apó vinte e cinco anos de efetivo exercício em funfões de magistério, com salário integral." (Item acrescentado pela Emenda Constitucional $\mathrm{n}^{\circ} 18$, de 30-6-81) (grifei)

Como se percebe, à evidência, pelo simples confronto dos textos, os dois dispositivos constitucionais em tela reproduzem, ipsis litteris, a mesma expressão condicionante da aposentadoria para os professores: "efetivo exercício de funções de magistério", expressão que, ao longo do tempo, e desde seu nascedouro, constituiu-se em perene fonte geratriz das mais acirradas polêmicas na busca de sua verdadeira e correta semân tica, a mais consentânea com as regras da Hermenêutica, tanto na esfera administrati-

$\mathrm{Na}$ "Proposta de Emenda à Constituição $\mathrm{n}^{\circ}$ 10, de 1981", dizem, na "justificativa", seus subscritores, com muita propriedade,

"Ao lado da família, o professor realiza a tarefa mais importante da sociedade. Po isso costumamos dizer que nele repousam as esperanças de todos os povos, principalmente daqueles que ainda não ultrapassaram a barreira do subdesenvolvimento.

À medida que crescem as comunidades e aumenta a complexidade dos serviços, mais e mais encargos são cometidos ao professor cidadão idealista e abnegado que dedica sua categoria daqueles denominados auto-aplicá-
Se ainda não foi encontrada uma fórmula capaz de minorar a aflitiva situação financeira dos professores; se o princípio federativo constitui obstáculo a que a União assuma a iniciativa dos Estados; se a situação financeira do País não permite aumento de despesa, que ao menos seja concedido aos mestres o benefício de uma aposentadoria especial, pois na realidade vinte e cinco anos de exercício do magistério correspondem a mais de 35 anos em outras atividades menos desgastantes."

Por sua vez, os formuladores da "Propos-

veis, pois se apresenta completo, dotado de todos os elementos necessários a sua imediata aplicação. Seguindo o ensinamento de Ruy Barbosa, pode-se afirmar que o direito instituído se acha 'armado por si mesmo, pela sua própria natureza, dos meios de execução e preservação', sendo-lhe 'supérfluo o auxílio supletivo da lei para exprimir tudo o que intenta e realizar tudo o que exprime'. (Comentários à Constituição Federal Brasileira. São Paulo, Saraiva, 1933, v. 2, pp. 488 e 492). Pela própria linguagem do texto verifica-se, exatamente, qual a conduta a seguir, não sendo preciso a edição de outras regras para seu cumprimento imediato."

No mesmo Parecer $n^{\circ} 4.802$ é, também, 1981", acrescentam:

"No momento em que pleiteamos a redução de tempo de serviço para efeito de aposentadoria do professor, estamos conscientes de que, sobre ser sumamente justa a presente proposta, em face dos sabidos desgastes físicos-anímicos que o magistério provoca naqueles que se dedicam à nobre missão de ensinar, ela é, ainda, um remédio possivel para minorar as agruras financeiras do nosso mal remunerado professor, ao permitir a ele, ainda com algumas energias sobrantes, face à diminuição do tempo de aposentar, aumentar os parcos rendimentos da aposentadoria como professor, com outra atividade laboral."

Inobstante a elogiável justeza de tais ponderações em relação à estóica e amargurada classe do Magistério, a aplicação da, afinal, aprovada Emenda Constitucional no 18 , de 30 de junho de 1981 , veio, de imediato, demonstrar que essa norma foi, por muitos, malsinada como condenável privilégio, arrostando, para poder vigorar, as mais restritivas e, até, facciosas interpretações, objetivando desestimular os pleitos consecutórios.

Uma das tantas maldosas insinuações sub-reptícias, tendentes a solapar a imediata vigência da nova regra constitucional, alegava não ser ela auto-aplicável. Contestando tal interpretação, a Procuradoria-Geral do Estado, no Parecer $n^{\circ} 4.802$, assevera, judiciosamente:

"...O preceito ora em exame se inclui na refutada a idéia equivocada ou tendenciosa de que a Emenda Constitucional n 18/81 consubstanciaria tão-só um princípio, dependente de legislação posterior. Como esclarece dito Parecer, a nova regra apresenta a declaração de um direito, que atua pelo mero fato de sua existência na Constituição, não dependendo de lei posterior para se realizar.

Em termos hermenêuticos, entretanto, o maior óbice enfrentado pela Emenda Constitucional no $18 / 81$ foi o mesmo que serve hoje de arrimo aos que, sem tréguas, tentam inviabilizar a vigência da norma inserta na Carta Magna no prefalado art. 40, III, $b$ : uma exegese, a mais estreita e restringente possível, no que concerne à determinação do verdadeiro destinatário do inquinado direito, cristalizado na controvertida expressão "efetivo exercício das funções de magistério".

Segundo a Procuradoria-Geral do Estado, no Parecer no 4.802, antes referido,

"No caso de funcionário público, ele é o professor que apresente efetivo exercício em funfóes de magistério, durante todo o tempo legalmente estipulado. Não basta exercer funções de magistério para ter direito à aposentadoria especial: é necessário prover cargo de Professor. Mas também não basta o provimento desse cargo, sendo igualmente indispensável o efetivo exercício em funções de magistério, durante todo o tempo constitucionalmente estipulado. Tem efetivo 
exercício em funções de magistério aquele professor que ensina, que ministra aulas, que exerce atividade docente.

Tratando-se de uma regra excepcional, não pode a norma contida na Emenda no $18 / 81$ sofrer outra interpretação que não seja a estrita (cfe. Carlos Maximiliano, Hermenêutica e Aplicação do Direito. $4^{\underline{a}}$ ed. Rio, Freitas Bastos, 1947. p. 252). Entendimento diverso levaria ao absurdo de se considerar como inútil ou supérflua a expressão "efetivo exercício em funções de magistério', o que também é inadmissível (cfe. Carlos Maximiliano, ob. cit., p. 303)."

Contrastando com tal exegese, extremamente rígida, e adotando visão mais panorâmica em relação à abrangência da norma constitucional sub examine, a então Secretaria de Pessoal Civil, da Administração Federal, no Parecer $n^{\circ} 299 / 82$ (DOU de 11-5deral, no Parecer $\mathrm{n}^{\circ} 299 / 82$ (DOU 8 , 847 ), ao manifestar-se sobre o exato alcance da expressão "efetivo exercício em funções de magistério", reproduz pronunciamento do Ministério da Educação e Cultura, consultado a respeito do assunto:

"Assim sendo, somente o tempo de serviço prestado em funções de magistério, consideradas estas 'as pertinentes à pesquis e ao ensino de graduação ou de nível mais elevado, que visem à produção, ampliação ou transmissão do saber; as que estendam à comunidade, sob forma de cursos e serviço especiais, as atividades de ensino e os resultados da pesquisa; as inerentes à direção ou assessoramento exercidas por professores na própria instituição ou em órgãos do Minis tério da Educação e Cultura' (art. 1ำ, Dec $\mathrm{n}^{\mathrm{o}} 85.487 / 80$ ), deve ser computado para efeito de aposentadoria, não se contando, para tal fim, o tempo de serviço estranho à carreira (informação de 19/11/81, constante do processo).

No que se refere ao Magistério de $1^{\circ}$ e $2^{\circ}$ Graus, O Decreto no 85.712 , de 16/02/82, Graus,
estatui:

'Art. $1^{\circ}$ - O magistério de $1^{\circ}$ e $2^{o}$ graus do Serviço Público Civil da União e das Autarquias mantidas pela União abrange tividades de preparação e ministração de ulas em disciplinas, áreas de estudo ou atividades, avaliação e acompanhamento de atividades discentes, no ensino de $1^{\circ}$ e $2^{\circ}$ Graus, na educação especial e pré-escolar, bem como atividades de administraşão escolar.

Parágrafo único - Compreendem-se nas atividades de administração escolar do magistério de $1^{\circ}$ e $2^{\circ}$ Graus aquelas inerentes à coordenação de curso, área ou disciplina e à direção, assessoramento e assistência em unidades ou órgãos com atribuições básicas pertinentes a ensino e, ainda, em unidades organizacionais do Ministério da Educação e Cultura, ligadas especificamente à educação e à cultura. (grifei).

$\mathrm{O}$ art. $2^{\circ}$ do Decreto $\mathrm{n}^{\circ} 59.676$, de 06/12/66 também já enumerava as atividades consideradas de magistério.

O legislador constituinte, na expressão 'efetivo exercício em funções de magistério' quis referir-se ao sentido consagrado na legislação ordinária. É considerado de 'efetivo exercício em funções de magistério' o tempo de serviço realmente prestado ou le galmente tido como efetivo, por ficção jurídica (grifei).

Portanto, no que se refere ao magistério federal, há de considerar-se as funções de magistério como especificadas nos transcritos arts. $1^{\circ}$ do Decreto $\mathrm{n}^{\circ} 85.487$, de 1981 , e do Decreto no 85.712, de 1981."

No âmbito da Previdência Social, o en tão Ministro Jair Soares, objetivando pôr ordem nas disparatadas interpretações formuladas em relação à nominada Emenda Constitucional no $18 / 81$, expediu a Portaria $\mathrm{n}^{2} 2.865$, de 06.5.82, que, adotando abrangente conceituação, resolveu:

"1 - Considerar como de efetivo exercício nas funçōes de magistério as atividades dos professores segurados da Previdencia Social urbana que, em estabelecimento de ensino de $1^{\circ}$ e $2^{\circ}$ graus, ou de ensino superior, bem como em cursos de formação profissional, autorizados ou reconhecidos pelos competentes órgãos do poder executivo federal ou estadual: a) exerçam atividades docentes, a qualquer título;

b) ocupem funções de administradores, planejadores, orientadores, supervisores, ou de outras específicas dos demais especialistas de educação.

2 - Incluem-se, também, como de efetivo exercício nas funções de magistério as atividades desenvolvidas pelos professores segurados da Previdência Social que nas universidades e nos estabelecimentos isolados de ensino superior sejam

a) pertinentes ao sistema indissociável de ensino e pesquisa, em nível de graduação, ou mais elevado, para fins de transmissão e ampliação do saber;

b) inerentes à administração."

$\mathrm{Na}$ esfera estadual, mesmo que, de início, como transparece do Parecer $n^{2} 4.802$, da Procuradoria-Geral do Estado, o Poder Executivo se apresentasse com uma postura acentuadamente rígida na exegese da norma constitucional concessiva da aposentadoria especial, foi ele, aos poucos, abrandando, por algum tempo, essa rigidez, como se percebe, claramente, por exemplo, no Parece no 4.864, da Procuradoria-Geral do Estado, em cujo bojo se vislumbra tal abrandamento, verbis:

"Ao adjetivo 'efetivo', que qualifica tempo de exercício em funções de magisté rio que dá ao professor o direito à aposentadoria antecipada, se há de conferir o entendimento tradicional do nosso direito administrativo, que reputa efetivo tanto o tem po de serviço realmente prestado quanto o legal mente assim considerado. Foi este também o entendimento do Departamento Administrativo do Serviço Público (DASP), em recente parecer de seu Coordenador de Legislação de Pessoal, onde se lê:

'O legislador constituinte, na expressão 'efetivo exercício em funções de magistério', quis referir-se ao sentido consagrado na legislação ordinária. É considerado de 'efetivo exercício em funçōes de magistério' o tempo de serviço realmente prestado ou legalmente tido como efetivo, por ficção jurídica'. (Revista da Procuradoria-Geral do
Estado, em Porto Alegre, 12(33):89 - 100 1982)."

Nessa linha de ampliação da abrangência semântica do étimo "funções de magistério", o Parecer no 5.518, da Procuradoria-Geral do Estado, ao abordar o tema controvertido, em termos de aposentadoria especial, da licença para qualificação profissional, cristalizou em sua ementa o seguinte entendimento:

"É computável para efeito de aposentadoria precoce do magistério o tempo em que o professor esteve afastado regularmente do exercício de suas funções, em gozo de licença para qualificação profissional (após a Lei $\mathrm{n}^{\mathrm{0}}$ 6.672/74) ou contemplado com bolsa de estudos (antes da Lei no $6.672 / 74$ )."

Buscando justificar esse posicionamento, o prefalado Parecer $n^{0} 5.518$ tece as seguintes ponderações:

"7. Se o afastamento do professor de suas atividades de magistério para fins de estudos sob a modalidade de licença para qualificação profissional se dá com vencimentos, e a sua efetividade é assegurada para todos os efeitos da carreira, importa ver a modalidade de efetivo exercício por ficção da lei. É certo que se poderia levantar objeção, buscando ver na expressão 'assegurada sua efetividade para todos os efeitos da carreira' a limitação dos efeitos da ficção jurídica à matéria de promoção. Todavia, parece que esse entendimento restritivo não é o melhor. Em primeiro lugar, porque o próprio texto não limita os efeitos da efetividade ficta a promoção tanto que expressamente assegura a mantença dos vencimentos. Em segundo lugar, porque este é o entendimento consagrado pelo próprio Poder Executivo Estadual, que ao regulamentar a matéria veio a estabelecer no artigo $1^{\circ}$ do Decreto $n^{\circ}$ 23.535, de 4 de dezembro de 1974, que a licença para qualificação profissional se daria sem prejuízo dos respectivos vencimentos, e assegurada a efetividade para todos os efeitos legais. Finalmente, porque um entendimento em contrário implicaria supor que o sistema legal estivesse em contradição procurando criar desestímulos para medidas que são simultaneamente objeto de in- 
centivos. Tiraria com uma mão o que dá com a outra. O que não se pode pressupor."

Não perdurou, entretanto, por lapso de tempo mais significativo essa postura magnânima do Poder Executivo em relação à aposentadoria especial do Magistério. Ao tornar público o Parecer no 7.700 , no DOE de 21-12-88, já sinalizava o Governo com clara e surpreendente reviravolta revisionista visando a uma exegese mais restringente da regra constitucional, a fim de que os "privilegiados" professores exercitassem com menos facilidades o direito inserto na Carta Magna.

Ao aprovar o Parecer em tela, decidiu o Sr. Governador:

"a) revogar, diante do entendimento do Colendo Tribunal de Contas do Estado e da evolução jurisprudencial, a orientação adotada no PARECER no 5.744/84-PGE, segundo a qual deveria ser computado como de efetivo exercício de magistério, para efeito da aposentadoria especial prevista no art. 39 (ou 40?), item III, letra $b$, da Constituição Federal, o tempo de serviço prestado por Professor colocado à disposição do Gabinete do Governador (Decreto $\mathrm{n}^{\mathrm{o}}$ $25.181 / 76$ ) ou requisitado, na forma do art. $5^{\circ}$ do Decreto $\mathrm{n}^{\mathrm{O}} 21.237 / 71$ (artigo 15 do Decreto $\mathrm{n}^{\circ}$ 25.957/77), para integrar Comissão de Processo Administrativo-Disciplinar na Procuradoria-Geral do Estado.

c) aos servidores em alusão, que forem surpreendidos pela providência do item a), será reconbecido o cômputo do tempo de exercício nos órgãos mencionados, como de efetivo exercício do magistério, até a data da revogação. (grifei).

Mais recentemente, essa "mudança de rota" se manifestou evidente e insofismável, ao arrepio, inclusive, do vetusto e consagrado brocardo Ubi lex non distinguit nec nos distinguere debemus. O Poder Executivo Estadual, pondo de lado o posicionamento favorável consubstanciado em diversos pareceres emanados da Procuradoria-Geral do Estado, assumiu uma postura extremamente radical, no sentido oposto, de tal sorte que deixou transparecer uma imagem verdadei- ramente contraditória e paradoxal, atingindo, em alguns casos, permissa venia, as fronteiras da arbitrariedade, eis que, adotando "dois pesos e duas medidas", terminou por perpetrar irreparáveis injustiças.

No intuito de justificar a rigorosa e drástica posição assumida, entendeu a Administração Pública Estadual de atrelar a contagem do tempo de serviço, para efeito de caracterização de "efetivo exercício de funções de magistério", à conditio sine qua non de que tal exercício se dê em instituição do Sistema Estadual de Ensino, com fulcro no art. $2^{\circ}$ da Lei RS no 6.672/74 - Estatuto e Plano de Carreira do Magistério Público do Rio Grande do Sul, combinado com o art. $7^{\circ}$ da Lei RS n $5.751 / 69$, que arrola as instituições de ensino integrantes do Sistema Estadual de Ensino.

Tal exegese vinculativa consubstancia, evidentemente, uma demasia, uma exorbitância; até, permissa venia, um lamentável equívoco, eis que o direito insofismável insculpido na Lei Maior não se afigura, em seu texto, jungido a tal pressuposto. Limita-se a Carta Magna a exigir "efetivo exercício em funçōes de magistério", sem, obviamente, cogitar do local onde devam elas ser exercidas, supondo-se, por evidente, que tal exercício tenha lugar em instituição oficial ou, pelo menos, reconhecida pelo órgão competente.

Se acatada tal exacerbação hermenêutica, chegar-se-ia à suprema aberração de negar aposentadoria especial ao professor estadual, integrante da carreira respectiva, que, nos termos do art. 58 da Lei RS nº 6.672/74 (Estatuto), fosse cedido, por exemplo, à Universidade Federal do Rio Grande do Sul, porque, como é óbvio, tal entidade não integra o Sistema Estadual de Ensino. Por não estar a mencionada Universidade abrangida pelo elenco (discutível) formulado pelo art. $7^{\circ}$ da citada Lei RS no 5.751/69, o professor em foco, mesmo ministrando re gularmente suas aulas, em instituição oficial, ficaria alijado do direito estatuído pela Lei Maior, eis que, segundo imposição do Poder Executivo, numa interpretaça estreita e bitolada do art. $2^{\circ}$ da Lei RS $n^{0} 6.672 / 74$, inciso $\mathrm{V}$, só é "atividade de magistério a dos Professores, a dos Especialistas de Educação e a diretamente ligada, no plano técnico-pedagógico, ao funcionamento do Sistema Esta dual de Ensino e ao aperfeiçoamento da educação". Tal ilação, evidentemente, não passa, permissa venia, de flagrante sofisma.

Na trilha desse raciocínio, não teria melhor sorte, em face dessa esdrúxula postura, o membro do Magistério Estadual que, posto à disposição, e.g., da Escola de Polícia, ali ministrasse aulas de sua habilitação específica (Lei $R S n^{\circ}$ 7.366/80, art. 48), pois tal instituição de ensino não está elencada no rol do mencionado art. $7^{\circ}$ da Lei RS $\mathrm{n}^{\circ}$ $5.751 / 69$, o que inviabilizaria a respectiva contagem de tempo para os efeitos do disposto no art. 40, III, $b$, da Constituição Federal, verdadeiro absurdo, por evidente.

Idêntico e inadmissível corolário ter-se-ia de inferir em relação aos professores que exercessem "funções de magistério", entre outras, na Academia de Polícia Militar (Lei RS n 6.196/71, art. 22), na Escola de Saúde Pública (Lei RS no 8.189/86, art. 18) ou na Escola do Serviço Penitenciário (Lei RS no $6.502 / 72$, art. $\left.4^{\circ}\right)$. Afigura-se, por óbvio, in integrum, descabida e absurda tal ilação, eis que essa subordinação do "exercício de funções de magistério" a instituição do Sistema Estadual de Ensino, representa um evidente plus, inexistente no texto constitucional, como referido acima, pois o mesmo institui o direito para quem comprove, apenas, "efetivo exercício de funçōes de magistério", sem, evidentemente, por despiciendo, cogitar de local de trabalho, desde que, como antes referido, sejam tais funções desempenhadas em instituições oficiais ou, pelo menos, reconhecidas pela autoridade competente. (Lei Fed. no 4.024/61, arts. 9ㅇ e 16; Lei RS no $4.724 / 64$, art. $6^{\circ}$ ).

A propósito do referido art. $2^{\circ}$ da Lei RS no 6.672/74, que define "Sistema Estadual de Ensino", "Pessoal do Magistério Público Estadual", "Professor", "Especialista de Educação" e "Atividade de Magistério", não se afigura despropositado lembrar que, em seu caput, dito dispositivo estabelece serem tais conceituações "para os efeitos desta Lei, de- terminando, de outra parte, no art. 97, que a aposentadoria e a disponibilidade do membro do Magistério regem-se pelas normas estabelecidas na Constituição, na legislaşão complementar e no Estatuto do Funcionário Público Civil do Estado."

Se, por conseguinte, a aposentadoria especial do professor está, na Lei Maior, cronologicamente, inclusive, posterior à lei local, condicionada, apenas, ao "efetivo exercício de funçóes de magistério, como admitir-se que exegese restritiva e exacerbada, e, como tal, cerceadora, inclua, como condicionante, seja a instituição onde se exercem tais funções integrante do Sistema Estadual de Ensino, como reivindica o Parecer no 8.961/91, da Procuradoria-Geral do Estado?

Se a norma constitucional hoje vigente, inserta no art. 40, III, $b$, é idêntica à da anterior Carta Magna, como demonstrado no início destas consideraçōes, afigura-se difícil à Procuradoria-Geral do Estado, hoje tão rigorosa e radical em sua posição, explicar os seguintes Pareceres:

5.282/83: "O professor cedido à $L B A$, por força de convênio destinado à realização de trabalho integrado SEC-LBA no setor educacional, que efetivamente exerce funções de Magistério no órgão cessionário, faz jus ao cômputo do tempo de serviço respectivo para a aposentadoria antecipada." (grifei).

5.452/83: "Aposentadoria de professora após 25 anos de efetivo exercício, em funções de Magistério. Adequação da expressão constitucional 'função de Magistério' à atividade desenvolvida por professor no exercício de função ligada a serviços de assistência educacional. O tempo de serviço prestado à Campanba Nacional de Alimentação Escolar constitui função de Magistério para os fins previstos na Emenda Constitucional $\mathrm{n}^{\circ}$ 18/81." (grifei).

5.734/84: "Aposentadoria de professora após 25 anos de efetivo exercício do Magistério. A professora cedida ao Instituto Nacional do Livro (INL), dentro do convênio MEC-SEC para exercer a coordenaga o regional do Programa Nacional de Bibliotecas, de- 
sempenhou funções equivalentes ao 'efetivo exercício do Magistério." (Grifei).

6.618/86: "Magistério. Aposentadoria especial (artigo 165, inciso XX, da Constituição Federal), ... Igualmente computável tempo de serviço na Presidência da Comissáo do Ano Internacional da Criança, para aposentadoria antecipada do professor..." (Grifei).

7.515/88: "Aposentadoria especial de membro do Magistério Estadual cedido ao Município para o exercício de funsãa de Secretário de Educaşão. Atividade de Magistério (!). Sistema Estadual de Ensino. Alteraf̧ão da conclusão do Parecer $n^{\circ}$ 7.305." (grifei).

8.122/89: "Vice-Prefeito. Não há impedimento, para que professora estadual, cedida ao Município, exerşa cargo de Secretária de Educação, mesmo sendo Vice-Prefeito. De acordo com o Parecer $\mathrm{n}^{\mathrm{Q}} 7.515 / 88$, desta Casa, o tempo de servigo será computável para aposentadoria especial previsto no art. 40, inciso III, letra $b$, da Constituição Federal. Havendo opção pela remuneração de Vice-Prefeito, aplica-se a regra do inciso $\mathrm{V}$, do artigo 38 da Constituição Federal." (grifei).

8.480/90: "Magistério. Aposentadoria Especial. Emprego de recreacionista da Prefeitura de Porto Alegre, exercido ainda como estudante de Escola Superior de Educasão Física. Possibilidade, diante das peculiaridades (!) da bipótese examinada." (grifei).

Em todas essas manifestações, parece flagrante o contraste entre a elástica interpretação nelas contida e o atual rigor exegético tendente a vincular a contagem de tempo de serviço em funções de Magistério ao seu exercício exclusivamente em instituição do Sistema Estadual de Ensino. Torna-se, realmente, difícil imaginar que a ele pertençam a LBA (Parecer 5.282/83), a Campanha Nacional de Alimentação Escolar (Parecer $5.452 / 83$ ), o Instituto Nacional do Livro (INL) (Parecer 6.618/86), o cargo de Secretário Municipal de Educação, intrínsecamente "político" (Pareceres 7.515/88 e $8.122 / 89$ ), bem como o emprego de recreacionista em Prefeitura Municipal (Parecer 8.480/90).

Nas hipóteses acima arroladas, sequer se poderia argüir, para justificação, serem ca- sos de "cedência", figura estatutária definida claramente na Lei RS nº 6.672/74 - Estatuto do Magistério, em seu art. 58:

"Art. 58 - Cedência é o ato através do qual o Secretário de Educação (e Cultura) coloca o professor ou especialista de educação, com ou sem vencimento, à disposição de entidade ou órgão que exerça atividade no campo educacional, sem vinculação administrativa à Secretaria de Educação (e Cultura)." (grifei).

Impende, neste passo, mais uma vez, perquirir: importa, constitucionalmente, para efeito de aposentadoria especial, indagar onde os beneficiários de tais Pareceres exerceram suas atividades, ou é mais importante verificar se os mesmos, realmente, exerceram, nas entidades mencionadas, as funçōes de Magistério inerentes aos cargos titulados?

Mesmo, ad argumentandum, que se configurasse, nos casos sub examine, a hipótese regular de "cedência", nos termos estatutários, não seria lógico, nem legítimo, concluir que, ipso facto, tais "cedências" implicariam rigorosamente contagem de "efetivo exercício de funções de Magistério", eis que, legalmente, poderia o professor ser "cedido" à instituição educacional e, inobstante, deixar de, efetivamente, exercer "funções de $\mathrm{Ma}$ gistério", stricto sensu, para ocupar-se, por exemplo, de atividades puramente burocráticas ou administrativas, estranhas ao ensino propriamente dito.

Afigura-se, pois, extremamente temerário igualar, linearmente, todas as solicitaçõeś de aposentadoria especial erigindo como princípio, simplista ou simplório, para concessão ou indeferimento, o de estar ou não sem uma real comprovação de "efetivo exercício de funções de Magistério", como exigido pela norma constitucional instituidora do direito.

"Interpretar uma expressão de Direito não é simplesmente tornar claro o respectivo dizer, abstratamente falando; é, sobretudo, revelar o sentido apropriado para a vida real, e conducente a uma decisão reta (Ennecerus e Max Salomon)". (Pedro Orlando, "No- víssimo Dicionário Jurídico Brasileiro", Vol. I, verbete "interpretar") (grifei)

"Interpretação. Do latim interpretatio, do verbo interpretare (explicar, traduzir, comentar, esclarecer), é compreendido, na acepção jurídica, como a 'tradução' do sentido ou do pensamento, que está contido na lei, na decisão, no ato ou no contrato.

Neste conceito, a 'interpretação' vem, em realidade, sondando a 'intenção' ali conti$\mathrm{da}$, fixar a inteligência verdadeira do que se interpreta para que assim se possa cumprir o pensamento do elaborador.

Mas, tendente a 'esclarecer' ou 'explicar', por outras palavras, o exato sentido contido em um 'escrito', não deve a 'interpretasão' ir além da inten fão presumidamente ali objetivada. Nesta razão, deve a interpretação esclarecê-la ou traduzi-la. mais para validá-la que para a anular.' (De Plácido e Silva, "Vocabulário Jurídico", Vd. I) (grifei).

Com esteio, precipuamente, nesta última assertiva do ilustre jurista, ousaria asseverar, com a devida vênia, que a Administração Pública Estadual, segundo deixa transparecer a radical e linear orientação imposta como regra genérica para análise dos pedidos de aposentadoria especial formulados pelos integrantes do Magistério Público, se mostra a priori mais inclinada a anular o direito insculpido na Lei Maior do que a validá-lo. Inúmeras aposentadorias têm sido negadas, segundo divulga amiúde o Diário Oficial do Estado, sob o fundamento de que o exercício da atividade de Magistério não se desenvolveu no "Sistema Estadual de Ensino", como se tal exigência fosse requisito constitucional para implemento do direito negado. Assim, por exemplo, a edição do dia 10-6-92, à fl. 08, estampa despacho do Sr. Secretário do Planejamento e da Administração, no Boletim nº 3431/92 - SPA, indeferindo aposentadoria especial, "por não implementar o mínimo de 25 anos de efetivo exercício de funções de magistério em órgão subordinado ao Sistema Estadual de Ensino. (grifei)

Esse indeferimento, de teor idêntico a tantos outros, diz respeito a integrante de um grupo numeroso de vítimas dessa mal- sinada orientação adotada pelo Estado. Formam-no os professores que, por lamentáve exerceram suas funções, durante muitos anos, em setores da Cultura, sendo, por isso, obrigados a, aleatória e compulsoriamente, atuar fora da Secretaria de Educação, eis que esta Pasta, intermitentemente, abrigou ou não a Cultura. Esses integrantes do Magistério Estadual tiveram seus pedidos de aposentadoria especial desconsiderados, por não se encontrarem, como alegado, no Sistema Estadual de Ensino, independentemente de terem exercido "funçōes de Magistério", como comprovadamente ocorreu, perpetrando-se, assim, lamentável injustiça, com fulcro, apenas, em linear e abstrato princípio, divorciado da realidade.

Tal postura, data venia, prima pela incongruência, eis que, como público e notório, a Secretaria de Educação, ao longo do tempo, andou, como referido, intermitentemente, aliada à Cultura, alternando-se entre Secretaria de Educação $e$ Cultura e Secretaria de Educação, sem que os professores nela lotados perdessem sua vinculação ao serem, coercitivamente, transpostos, com os respectivos órgãos de lotação, para outros, desvinculados, eventualmente, da Pasta da Educação. Nesse sentido, se admitida a exegese imposta pela Administração Pública Estadual, chegar-se-ia, provavelmente, ao absurdo de conceder a aposentadoria especial aos mencionados professores, enquanto em exercício na Secretaria de Educação e Cultura, negando-a, entretanto, no instante em que, por força de desmembramento, passassem a atuar na Secretaria de Cultura ou órgão equivalente, sem se indagar se nesse novo local de trabalho continuaram a exercer a mesma atividade que vinham desenvolvendo.

A Secretaria de Educação, pelo Decreto no 578, de 22-7-42, passou a denominar-se "Secretaria de Educação e Cultura" (Artigo $1^{\circ}$ ), englobando, entre suas instituições de educaşão extra-escolar, o Museu do Estado e Arquivo Histórico, a Biblioteca Pública e o Teatro São Pedro. Essa estrutura foi, basicamente, mantida pelo Decreto-Lei $n^{2} 246$, de 13-10-42, que deu nova organizaçã̉o à Pasta. 
Depois de passar por nova estrutura, com o Decreto $n^{\circ} 17.750 / 65$, teve a Secretaria de Educação e Cultura, com o Decreto $\mathrm{n}$ - 21.120, de 17-5-71, significativa reorganização, figurando, entre seus Conselhos, o de Cultura, e, entre os Departamentos, o de Assuntos Culturais (DAC) (Art. 1ㅇ, I, 2 e V 4). Essa estrutura, praticamente, foi mantida pela organização protagonizada pelo $\mathrm{De}$ creto $\mathrm{n}^{\circ}$ 21.843, de 7-7-72 (Art. $1^{\circ}$ ).

Em 15-3-79, com o Decreto no 28.650 que alterou a estrutura organizacional da Administração Direta, passou a Secretaria a ser apenas de EDUCAÇÃO (Art. 1, VIII), com a criação da Secretaria de CULTURA DESPORTO E TURISMO (Art. 1으, XI). Essa organização foi completada pelo Decreto $\mathrm{n}^{\mathrm{9}} 28.654$, de 22-3-79, e, ainda, pelo Decreto $n^{\circ} 28.709$, de 4-5-79, que transferiu, da Secretaria de Educação para a Secretaria de Cultura, Desporto e Turismo, o Departamento de Assuntos Culturais (DAC) e o Conselho Estadual de Cultura (Arts. $1^{\circ}$ e $2^{2}$ ).

Este último decreto, em seu art. $4^{2}$, estabelece:

"Art. 4으. Ficam relotados na Secretaria de Cultura, Desporto e Turismo, com os respectivos titulares, os cargos em comissão, funções gratificadas e os cargos de provimento efetivo dos órgãos transferidos, bem como os servidores extranumerários e contratados em exercício nos mesmos.

Parágrafo único - Excetuam-se do disposto neste artigo os cargos de provimento efetivo de membros do Magistério Público Estadual e os professores extranumerários e contratados.

Art. $5^{2}$ - Os membros do Magistério Estadual, inclusive extranumerários e contratados, que na data da publicação deste Decreto se encontrem em exercício no Departamento de Assuntos Culturais retornarão à Secretaria de Educaşão à medida que forem sendo dispensados das tarefas que vêm desempenbando." (grifei).

Para impedir que os professores em exercício na Secretaria de Cultura, Desporto e Turismo sofressem prejuízo na carreira, em

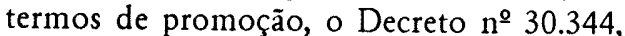
de 5-10-81, acrescentou parágrafo único ao art. 28 do Decreto no $29.847 m$ de $15-10-80$
(Regulamento de Promoções do Magistério Público), que ficou assim redigido:

"Art. 28 - A partir de 14 de outubro de 1980, o membro do Magistério que estiver à disposição da União, de outras Unidades da Federação ou de qualquer Órgão não vinculado à área educacional, com ou sem ônus para o Estado, concorrerá à promoção somente por antiguidade, salvo o disposto no Decreto $\mathrm{n}^{\mathrm{0}} 25.181$, de 20 de dezembro de 1978, art. $2^{\circ}$

Parágrafo único - $O$ disposto neste artigo não se aplica aos membros do Magistério Público Estadual de que trata o art. 5o do Decreto no 28.709, de 4-5-79." (Pessoal em exercício no Departamento de Assuntos Culturais) (Grifei).

Em 26.3.82, com a edição do Decreto no 30.602, várias instituiçóes da Secretaria de Cultura, Desporto e Turismo foram transferidas para a Secretaria de Educasão (Art. $1^{\circ}$ ), merecendo destaque, além de quatro Bibliotecas, as Escolinhas de Arte "Carlos Barone", de Passo Fundo, "Odessa Macedo", de Bagé, e "Infanto-Juvenil" (Centro de Desenvolvimento de Expressão), de Porto Alegre, onde membros do Magistério, seguramente, exerceram atividades docentes especializadas, não reconhecidas, porém, pela esdrúxula decisão do Governo Estadual de só admitir, para a aposentadoria especial, tempo de serviço em instituição tutelada pela Secretaria de Educação.

Nesta hipótese sub examine, é possível perceber, à evidência, o absurdo da determinação governamental: os mesmos professores, na mesma escola, enquanto colocada, por artifício legal, no âmbito da Secretaria de Educação, teriam, possivelmente, admitido, como tempo de serviço aproveitável para a aposentadoria especial, o exercido nesse período, não o tendo, entretanto, reconhecido quando referente à Secretaria de Cultura, onde se situava anteriormente à transposição a mesma Escola. Realmente, um paradoxo.

Aliás, a propósito, cumpre lembrar que esse Decreto $\mathrm{n}^{\circ} 30.602 / 82$, em seu art. $4^{\circ}$, estabelece:
"Art. 4 - Os membros do Magistério Estadual, inclusive extranumerários e contratados, que na data da publicação deste Decreto se encontrem em exercício nas instituifões mencionadas no art. $1^{\circ}$ deste Decreto, retornam à Secretaria de Educaşão." (grifei).

Impende, de outra parte, mencionar, para um mais correto e justo ajuizamento do transtorno funcional sofrido pelos professores que atuaram nessas Escolinhas de Arte, que as mesmas, depois de, pelos Decretos $n^{2} s$ 31.753/84 e 32.558/87, terem mudado sua denominação para "Centro de Desenvolvimento da Expressão", foram, pelos Decretos nos $32.782 / 88$ (Art. $1^{\circ}$ ) e $33.735 / 90$ (Art. $1^{\circ}$ ), que alteraram o art. $2^{\circ}$ do Decreto $\mathrm{n}^{\circ} 32.558 / 87$, subordinadas, respectivamente, ao Conselho Estadual de Desenvolvimento Cultural e, após, à Secretaria de Cultura, criada pela Lei no $9.117 / 90$.

Em 15-3-83, pelo Decreto no 31.120, voltou, novamente, a Secretaria de Educação a ser Secretaria de Educação e Cultura (Art. $1^{\circ}$, VIII), sendo para ela transferidos (Art. $\left.2^{\circ}\right)$ os Departamentos de Cultura e de Desportos e os Conselhos Estadual de Cultura e Regional de Desportos ( $\$ 1^{\circ}$ ), criando-se, simultaneamente, as Subsecretarias de Cultura e a de Desportos.

Mais uma vez, pelo art. $6^{\circ}$ desse Decreto $\mathrm{n}^{\circ} 31.120 / 83$, ficou determinado:

"Art. 60 - Os membros do magistério estadual e os demais servidores, inclusive extranumerários e contratados, que, na data da publicação deste Decreto, se encontrarem cedidos ou à disposição da Secretaria de Cultura, Desporto e Turismo, em exercício nos Departamentos transferidos, conforme artigo $2^{\circ}$, deste Decreto, retornarão às suas repartiçóes de origem." (grifei)

Em 15-3-87, novamente, com a criação do Conselho Estadual de Desenvolvimento Cultural, pelo Decreto $\mathrm{n}^{\circ} 32.515$ (Art. $8^{\circ}$. $c$ ), voltou a Secretaria de Educação e Cultura a ser, mais uma vez, apenas Secretaria de Educação, em face do Decreto $\mathrm{n}^{\circ} 32.516$, da mesma data, que alterou denominação $e$ atribuições de Secretarias (Art. 1ํ, VIII), tendo o Decreto $\mathrm{n}^{\mathrm{0}} 33.314 / 87$ acrescentado ao art. $1^{\circ}$ do mencionado $\mathrm{n}^{\circ} 32.516$ o inciso
XIV, relativo à recriada Secretaria de Cultura, Turismo e Desporto.

Em 21-4-87, pelo Decreto $n^{\circ} 32.543$, foi estabelecida a organização do Conselho Estadual de Desenvolvimento Cultural, sendo, em 10-7-87, pelo Decreto $\mathrm{n}^{\mathrm{Q}} 32.580$ (alterado pelo Decreto $\mathrm{n}^{\circ} 32.622 / 87$ ), extinta a Subsecretaria de Cultura, determinando seu art. $2^{\circ}$ :

"Art. $2^{\circ}$ - Os funcionários, os membros do Magistério Estadual e inclusive os servidores contratados e extranumerários com exercicio na Subsecretaria de Cultura ficam trans feridos para o Conselho Estadual de Desenvolvimento Cultural, de que tratam os Decretos no s 32.515, de 15 de março de 1987, e 32.543, de 21 de abril de 1987.

Parágrafo único - De acordo com o seu programa de recursos humanos, o Conselho Estadual de Desenvolvimento Cultural reencaminhará à Secretaria de Educasãa os servidores que excederem de suas necessidades, para aproveitamento em outras unidades de trabalho." (grifei)

Como acima mencionado, este artigo teve sua redação alterada pelo Decreto $n^{\circ}$ 32.622 , de 17-9-87, ficando assim redigido:

"Art. $2^{\circ}$ - Os funcionários, os membros do Magistério Estadual e inclusive os servidores contratados e extranumerários com exercício na Subsecretaria de Cultura permanecem com suas atuais vinculasooes, servindo no Conselho Estadual de Desenvolvimento Cultural, criado pelos Decretos nos 32.515 , de 15 de março de 1987 e 32.543 , de 21 de abril de 1987." (grifei)

Em 29-9-89, foi editado o Decreto $\mathrm{n}^{\mathrm{9}}$ 33.314 , que, como antes referido, ao alterar o Decreto $n^{\circ} 32.516 / 87$, além de acrescer o item XIV ao art. $1^{\circ}$, relativo à Secretaria de Cultura, Turismo e Desporto, transferiu, no art. 4⿳, para a mesma, o Conselho Estadual de Desenvolvimento Cultural (reorganizado pelo Decreto $n^{\circ}$ 33.316, de 29-9-89), o Conselho Regional de Desportos e a Subsecretaria de Desporto da Secretaria de Educação, estabelecendo, em seu art. $6^{\circ}$ :

"Art. 60 - Ficam relotados na Secretaria de Cultura, Turismo e Desporto, com os respectivos titulares, os cargos em comissão, 
funções gratificadas e cargos de provimento efetivo dos órgãos transferidos, bem como os servidores extranumerários e contratados em exercício nos mesmos.

Parágrafo único - Excetuam-se do disposto neste artigo os titulares de cargos de provimento efetivo do Magistério Público Estadual e os professores extranumerários e contratados, que passam a servir nos órgãos transferidos, mantendo suas atuais vinculaşões. (grifei).

Finalmente, em 23-7-90, pela Lei RS n 9.117, foi criada a Secretaria de Cultur determinando o parágrafo único do art. $4^{\circ}$ "Art. 4 - ..

Parágrafo único - Aos membros do Quadro da Carreira do Magistério Público Estadual, do Quadro Único do Magistério Pú blico do Estado e aos admitidos para o Magistério sob o regime da Lei no 1.937 , de 22 de fevereiro de 1965, em exercício no Conselho de Desenvolvimento Cultural e nos órgãos que o integram, fica assegurada no prazo de 90 (noventa) dias, a contar da publicação do Regimento da Secretaria da Cultura, a opção pela permanência no atua exercício." (grifei).

Em 27.11.91, publicava o Diário Oficial do Estado a Lei no 9.433 , da mesma data, dispondo sobre a estrutura organizacional da Administração Direta, mantendo, parece, definitivamente separadas a EDUCACÃO e a CULTURA, cada Secretaria co suas áreas de competência definidas no art. 4을 incisos VII e VIII.

Diante dessa espantosa cronologia, recendendo a ficção, ou insinuando tragicomedia, pelo inter minável e inusitado "vaivem" a que foram submetidos os professores atingidos por tantas alterações na denominação da Pasta Educacional, com sucessivas anexações e desanexações da Cultura, uma verdade, pelo menos, restou clar e irretorquível: nunca deixaram os membros do Magistério de ter sua vinculação à Secretaria da Educação garantida expressamente, nos inúmeros atos editados, mantendo incólumes os cargos titulados. Não foram, portanto, 'cedidos' nem 'postos disposição'. Acompanharam, simplesmente, como "acessórios", os respectivos órgãos em

Impende, então, nesse passo, reindagar pode-se, linearmente, a priori, negar a todos os submetidos a essa verdadeira "tortura" (ice exercício de suas atribuições funcionais nessas áreas mencionadas da Cultura, simplesmente por estarem as mesmas, eventualmente, fora da esfera administrativa da Secretaria da Educação, sem perquirir o tipo de atividade exercida, pelo menos, sabendo-se, como foi salientado, que, por disposição legal expressa, todos tiveram sua vinculação à Pasta Educacional resguardada?

No Egrégio Tribunal de Justiça do Rio Grande do Sul, ao julgar o mandado de segurança $n^{\circ} 588025411$ (RJTJRGS $n^{2} 135$, pág. 129), refere, em seu voto, o eminente Relator:

"O 'efetivo exercício em funções de magistério' para o gozo de aposentadoria especial para os professores em trinta anos para as professoras em vinte e cinco anos, segundo a Emenda Constitucional no $18 / 81$, não tem a conotaşão de, apenas, exercício de aulas, tanto que se refere a funçôes de magistério.

Existem exceções que devem ser admitidas, entre as quais a jurisprudência desta Corte, bem como o STF vêm reiteradamente confirmando." (grifei).

Por sua vez, o Egrégio 2 Grupo de Câmaras Cíveis do TJRGS, no julgamento do mandado de segurança $\mathrm{n}^{\circ} 588021147$, salienta, pela palavra de seu ilustre Relator RJTJRGS n 135 , pág. 125):

"...Por fim, é oportuno lembrar que nossa Suprema Corte, em sessão plenária de 21.8.86, já se pronunciou sobre o exato significado do predito preceito constituciona (RJTJRGS, 120/15, fl. 42). O então Relator, minente Min. Octávio Gallotti, manifes tou, em seu voto, 'que a expressão 'efetivo exercício em funções', utilizada pelo legisador constituinte tem como escopo, a exlusão do tempo dedicado ao desempenbo de atribuigóes estranbas ao professorado.
Daí a referência do texto a 'funções', para exigir que sejam estas de magistério e não apenas, dessa categoria, o cargo ou emprego ocupados pelo servidor" (grifei).

Em face dessas judiciosas, objetivas e claras assertivas, afiguram-se, s.m.j., suficientemente justificadas as ponderações aqui expendidas a respeito do polêmico assunto. Evidencia-se, inquestionavelmente, como salienta o insigne Ministro Gallotti, não se primordial, para o correto desate da quaestio juris, a titulação de cargo de magistério, ou melhor, ser de magistério o cargo titulado, muito menos, ainda, por via de conseqüência, onde ele é desempenhado. Imprescindível, sem dúvida, se faz serem de magistério as funções de fato exercidas pelo titular do cargo, não se coadunando, por conseguinte, com tal entendimento, por inteira incompatibilidade, qualquer radicalismo exacerbado conducente a um prévio e injusto cerceamento do direito consagrado na vigente Le Maior, confirmativa do já insculpido na anterior pela comentada Emenda no $18 / 81$ como ocorre, e.g., quando se erige, como fundamento absoluto $e$ inarredável, um princípio despótico, que inadmite a indivi dualização, partindo, sempre, para a generalização devastadora.

Impende, obviamente, reconhecer a eventual existência de justo dissídio no que concerne ao exato alcance da expressão "efetivo exercício em funções de magistério", em determinadas hipóteses, como, por exemplo em relação ao desempenho das funções de "Secretário Municipal de Educação". Inobs tante, na referência feita aos Pareceres da Procuradoria-Geral do Estado, favoráveis contagem desse tempo de serviço para a aposentadoria especial, registrássemos nossa desconformidade com as conclusões dos mesmos, por tratar-se de atividade tipicamente político-administrativa, impõe-se admitir significativa divergência na exegese $d$ hipótese, como ficou patente no julgamento do mandado de segurança $n^{2} 588006429$ no $2^{\circ}$ Grupo de Câmaras Cíveis do Egrégio Tribunal de Justiça do Estado do RGSul (RJTJRGS no 132, 246/253), decidido favoravelmente, por maioria.
Em seu voto deferitório, assevera o emminente Relator:

"Estamos frente a uma relação jurídica de direito público na qual o sujeito originário ao qual se ligava a impetrante como professora estadual cedeu-a para um sujeito derivado, municipal, conservando o vínculo estatutário estadual, baseado num puro interesse público, vindo ela a prestar seu serviços, como Secretária de Educação do Município de ... O direito líquido e certo da impetrante é um direito previsto expressamente na Constituição, art. 165, XX, mas ele é relativo, em função de sua finalidade. No caso, a impetrante desempenhou, em todos os vinte e cinco anos de trabalho uma atividade voltada para o interesse público, em função do magistério. Assim, entendemos o trabalho desenvolvido quer na sala de aula, ministrando as disciplinas curriculares, quer na Secretaria Municipal de Educação, subministrando àquelas professoras subordinadas a esta pasta política desenvolvida pelo Município de... em função de magistério municipal.

O direito, com sede constitucional, interpreta-se restritivamente sem excluir a ra cionalidade das funções desenvolvidas. Se as atividades todas gravitam nas funções de magistério, o direito à aposentadoria voluntária invocado é líquido e certo; se assim não fora, a professora que em sua escola desenvolvesse tarefas próprias - as ditas especialistas em educação, por determinação da Secretaria de Educação, ou que se aposentasse por licença para qualificação profissional - não poderia obter aposentadoria especial aos vinte e cinco anos de serviço em funções de magistério. Se o governo crê que os direitos só serão adquiridos pelo exercício pleno da função para a qual o funcionário foi concursado e investido no cargo, deveria, por coerência, eliminar todas as possibilidades de colocar funcioná rios públicos em desvio de função. Suprimidas as cedências, o administrador público teria sempre em mãos o pleno controle do seus funcionários, jungindo-os às tarefas para as quais se habilitaram por concurso. 
Impende, entretanto, gizar que os votos vencidos, com elogiável acuidade, registram que

... o Secretário Municipal exerce uma função de natureza política, não necessitando ele de qualquer qualificação profissioal ou técnica para exercer suas funções. Basta estar no exercício dos direitos políticos e ter a idade mínima exigida em lei. Qualquer um pode ser Secretário de Educação; logo, conclui-se daí que quem exercer essas funções não está exercendo 'funções de magistério', como exige a Lei Maior. Por isso, no caso concreto, descabe a aposentadoria especial."

De qualquer maneira, tal discrepância na interpretação da norma constitucional sub examine, concessiva da aposentadoria antecipada, não cinge a controvérsia ao campo restrito a que pretende conduzir a discussão a Administração Pública Estadual, ao bitolar a área de atuação dos professores estaduais à formada pelas entidades do Sistema Estadual de Ensino. In medio stat virtus, sem dúvida. Como assevera, com extrema propriedade, o ilustre Relator do acórdão transcrito, "o direito, com sede constitucional, interpreta-se restritivamente sem excluir a racionalidade das funfooes desenvolvidas". A regra consubstanciadora do direito em tela deve, como constitucional, ser contemplada com visão restritiva; não, porém, a tal ponto de levar à cegueira.

As "funçōes de magistério", criteriosamente arroladas no citado Parecer 299/82 da então Secretraria de Pessoal Civil, da União, não se podem confinar, como ali judiciosamente explicitado, ao diminuto re cinto de uma sala de aula, de uma determinada instituição, de um determinado sistema devendo, ao contrário, obrigatoriamente incluir toda a gama de atividades que, de alguma forma, casam com a idéia de magis tério, exercidas, de fato, onde quer que seja, resguardado, como é óbvio, o pré-requisito de tratar-se de curso oficial ou, pelo menos, reconbecido pelo órgão competente. Como sabiamente sublinharam em sua "Justificati va" os subscritores de uma das Emendas
Constitucionais referidas anteriormente, a de $\mathrm{n}^{-} 10$, visando à aposentadoria especial,

"à medida que crescem as comunidades e aumenta a complexidade dos serviços, mais e mais encargos são cometidos ao professor, cidadão idealista e abnegado que dedica sua vida à nobre tarefa de servir."

Inobstante essa ampla visão espectral das variadas funções docentes abra vasta perspectiva para uma compreensão a mais justa possível da mens legis do polêmico dispositivo constitucional em tela, difícil se afigura o acolhimento da recém-promulgada Lei $\mathrm{n}^{\mathrm{0}}$ 9.481, de 16-3-93 (DOE de 16-3-93), que "dispõe sobre a aposentadoria especial estabelecida no art. 38, III, $b$, da Constituição do Estado" (reprodução literal do discutido art. 40, III, $b$, da Lei Maior federal).

Essa norma (Lei no 9.481/93), cuja vigência vem de ser sustada pelo Egrégio Supremo Tribunal Federal, através de concessão de liminar em ação intentada pelo Governo do Estado (Correio do Povo de 24-4-93, pág. 08), dispõe, ultrapassando os lindes do razoável, verbis:

"Art. 1ำ - Considerar-se-ão como de efetivo exercício nas funções de magistério, para os efeitos da aposentadoria de que trata art. 38, III, $b$, da Constituição do Estado, as atividades docentes, a qualquer título, as administrativas, as técnico-pedagógicas outras específicas dos demais especialistas em educação exercidas em estabelecimentos de $1^{\circ}$ e $2^{\circ}$ graus ou em nível de Sistema Estadual de Ensino.

Parágrafo único - Considerar-se-á, tam bém, como de efetivo exercício nas funções de magistério, o período em que o servidor ocupar cargo de representação associativa ou sindical do Quadro do Magistério Público Estadual."

Além de vazada em termos confusos, ambíguos e contraditórios, a lei em foco contém verdadeiros absurdos, como no pará grafo único do transcrito art. 10, ao consagrar como de efetivo exercício de funções de magistério o desempenho de cargo (!) de representação associativa ou sindical do Quadro do Magistério Público Estadual (!).
Antes de mais nada, impende presumir que o "cargo de representação" pertença a uma Associação ou a Sindicato, e não, evidentemente, ao "Quadro do Magistério Público Estadual", como faz supor o mal-elaborado texto legal, pois esse Quadro, criado pelo art. 148 da Lei no 6.672/74 (Estatuto) constituído de cargos de Professor e de Especialista de Educação, não prevê "cargos de representação", nem a norma estatutária em seu art. $2^{\circ}$, itens III e IV, ao definir as funções atribuídas, respectivamente, aos Professores e Especialistas de Educação, faz qualquer referência a tal "representação". Permite, apenas, a Lei $n^{\circ} 6.672 / 74$, em seu art. 153, que o professor ou especialista d educação, eleito regularmente para função executiva em entidade de classe do Magisté rio, em âmbito estadual ou nacional, poss ser dispensado, pelo Chefe do Poder Executivo, de suas atividades funcionais, sem qualquer prejuízo, não se podendo, obviamente, tomar a acepção de tal étimo em termos absolutos. Basta, para tanto, que se tenha presente o disposto no art. 27, II, da Constituição do Estado, que assegura

"aos representantes das entidades mencionadas no inciso anterior (sindicatos associações dos servidores da administração direta e indireta), nos casos previstos em lei, o desempenho, com dispensa de suas atividades funcionais, de mandato em confederação, federação, sindicato e associação de servidores públicos, sem qualquer prejuízo para sua situação funcional ou remuneratória, exceto promoşão por merecimento".

Admitir, portanto, a contagem de tal tempo para efeito de promoção por antigüidade, como se infere do texto transcrito, ou, mesmo, por extensão, para aposentadoria aos 35 anos, se homem, e aos trinta, se mulher (Constituição Federal, art. 40, III a), afigura-se, até, plausível. Considerar, porém, esse tempo de exercício de "cargo" em associação de classe ou sindicato como se de "magistério" fosse, parece inquestionável extrapolação das raias de uma sensata hermenêutica da norma insculpida na Carta Magna federal, no prefalado art. 40, III, $b$, atingindo os páramos da ficção.
O Egrégio Tribunal de Justiça do RGSul, em acórdão unânime do $2^{\circ}$ Grupo de Câmaras Cíveis, ao julgar, em 08.11.91, o MS no 591.083.993, teve ensejo de abordar o tema em foco, decidindo:

"Se o período no qual a impetrante trabalhou na Associação dos Administradores Educacionais não caracteriza efetivo exercício em função de magistério, seja, não ministrou, como professora, em sala de aula, cultura a alunos do Sistema Estadual de Ensino, não deixou de ser professora, por isso todas as vantagens do cargo lhe foram asseguradas, mas como não lecionou no sentido próprio da palavra não pode obter aposentadoria especial." (COAD/ADV, Informativo Semanal 05/92 - Jurisprudência 57134).

No mesmo sentido, o Egrégio Superior Tribunal de Justiça, em acórdão unânime da $2^{2}$ T., publ. em 04.02.91, assim se manifestou:

"É incensurável a decisão que, em face da taxatividade do texto constitucional, restrito ao exercício do magistério, denega a segurança requerida por professora, a fim de contar, para fins de aposentadoria aos 25 anos, o tempo em que exerceu o cargo de tesoureira do Centro Estadual de Professo res." (COAD/ADV, Informativo Semanal 11/91 - Jurisprudência - 53229).

No que concerne ao caput do art. $1^{\circ} \mathrm{d}$ mencionada Lei $\mathrm{n}^{\circ} 9.481 / 93$, está o mesmo formulado, como anteriormente referido, em termos confusos, ambíguos e contraditórios.

Estabelece, por exemplo, que se consideram funçōes de Magistério as atividades "téc nico-pedagógicas e outras específicas dos demais especialistas em educaşão".

Ao referir-se aos "demais" especialistas, a qual ou quais categorias de especialistas se reporta fazendo menção a atividades "técnico-pedagógicas"? O Estatuto do Magistério Público Estadual (Lei n 6.672/74), ao definir, em seu art. $2^{\circ}, V$, "atividade de Magistério", inclui, no "plano técnico-pedagógico", tanto a dos Professores quanto a dos Especialistas de Educação. Evidente, portanto, a erronia da lei em foco (9.481/93), que, também, incorre, nesse aspecto, em cla- 
ro descompasso com o dispositivo estatutário citado ao incluir, como função de $\mathrm{Ma}$ gistério, a atividade administrativa. Nele está, com limpidez, declarada como "atividade de Magistério a dos Professores, a dos Especialistas de Educação e a diretamente ligada, no plano técnico-pedagógico, ao funcionamento do Sistema Estadual de Ensino e ao aperfeiçoamento da educação".

Em outro tópico, dispõe o mencionado $c a$ put do art. $1^{2}$ da Lei no $9.481 / 93$ que as consideradas funções de Magistério serão as exercidas "em estabelecimentos de $1^{\circ}$ e $2^{\circ}$ graus ou em nível de Sistema Estadual de Ensino".

Afigura-se induvidoso que, nessa locução, a conjunção alternativa OU torna o texto indecifrável, constituindo ela, segundo se pode inferir, evidente demasia. $A$ contrario sensu, confirmando-se a alternativa, o Sistema Estadual de Ensino não englobaria estabelecimentos de $1^{\circ}$ e $2^{\circ}$ graus, resultando, disso, verdadeiro contra-senso.

A propósito, afigura-se, no mínimo, estranho que a Lei $n^{\circ} 9.481 / 93$ faça referência, tão-só, aos estabelecimentos de $1^{\circ}$ e $2^{\circ}$ graus, quando a Constituição do Estado, em seu art. 206, dissentindo, aliás, do art. $7^{\circ}$ da Lei $n^{\circ}$ 5.751/69 (Sistema Estadual de Ensino), estatui:

"O sistema estadual de ensino compreende as instituiçōes de educação pré-escolar e de ensino fundamental e médio, da rede pública e privada, e os órgãos do Poder Executivo responsáveis pela formulação das políticas educacionais e sua administração."
Em face desse dispositivo constitucional, como interpretar a alternativa legal acima enfocada? Os eventuais hermeneutas serão, em sombra de dúvida, compelidos a exacerbante exercício de imaginação...

De todo o exposto, impende concluir, forçosa e lamentavelmente, que a Lei $\mathrm{n}^{\circ}$ $9.481 / 93$, ao invés de dissipar as dúvidas existentes no que concerne ao correto entendimento do que sejam, realmente, "funções de Magistério", veio, na verdade, obscurecer ainda mais a turva e confusa visão reinante quanto à correta interpretação do art. 40, III, $b$, da Lei Maior federal, instituidor da aposentadoria especial para os exercentes de funfóes de magistério.

Com a devida vênia, ainda se nos afigura mais condizente com a mens legislatoris a posição que modestamente, defendemos nas ponderações expendidas e que, sem incorrer em demasia, vale repetir:

"As funções de magistério, criteriosamente arroladas no citado Parecer 299/82, da então Secretaria de Pessoal Civil, da União, não se podem confinar, como ali judiciosamente explicitado, ao diminuto recinto de uma sala de aula, de uma determinada instituição, de um determinado sistema, devendo, ao contrário, obrigatoriamente, inatividades que, de alguma forma, casam com a idéia de magistério, exercidas, de fato, onde quer que seja, resguardado, como é óbvio, o pré-requisito de tratar-se de curso oficial ou, pelo menos, reconbecido pelo órgão competente."

\section{Procedimentos ordinário e sumaríssimo}

Ovídio A. Baptista da Silva

Professor Titular de Direito Processual Civil da Faculdade de Direito da UFRGS

\section{Abstract}

The paper analyses the theoretical bases of the Ordinary Procedure and prove, that his essential nature is not founded in the complete judicial knowledge. We can identify the Ordinary Procedure like the modern expression of the "ordo judiciorum privatorum" of the Roman Private Law. The author suggests to create alternatives'ways in order to preserve the instrumental nature of the Procedure.

\section{Resumo}

O estudo procura mostrar as raízes teóricas do procedimento comum, ordinário e sumaríssimo, desfazendo, inicialmente o equívoco em que incidem aqueles que supõem ser a ordinariedade um fenômeno decorrente da "plenariedade" da cognição judicial. Estabelecido o conceito de procedimento ordinário como a expressão moderna do procedimento do ordo judiciorum privatorum do direito privado romano, propōe-se o autor desvendar os inconvenientes mais notórios da universalização do rito ordinário, sugerindo a criação de caminhos alternativos através da diferenciação ritual, única maneira de preservar o sentido de instrumentalidade ao processo.

1. O vigente Código de Processo Civil brasileiro, fiel a uma tradição secular que o liga ao direito romano, adota o Procedimento Ordinário como forma ritual padrão, de onde as demais formas especiais de procedimento que, por uma ou outra razão, não sigam a ordinariedade, devem retirar as re- gras complementares que haverão de preencher a ausência de disciplina específica.

O Procedimento Ordinário desempenha, portanto, em nosso direito, uma tríplice função: a) serve de parâmetro para os de mais procedimentos não-ordinários; $b$ ) fornece-lhes, a estes procedimentos, regras suplementares, sempre que o legislador não as inscreva como exigência da especialidade; $c$ ) será o procedimento a ser adotado tanto que superados os motivos determinantes da especialidade procedimental, de modo que toda ação passa a ser ordinária, depois de ultrapassadas a fase ou o incidente que determinam sua diversidade ritual.

2. A doutrina em geral não se preocupa com a gênese das instituições e categorias jurídicas próprias do direito processual civil, sendo raro encontrarem-se, em manuais universitários e mesmo em tratados, referências de algum valor às origens do Procedimento Ordinário que, em geral, é dado como um pressuposto lógico, ou uma premissa teórica, de todo o discurso prático, a respeito da qual não se discute, como se a ordinariedade fosse um fenômeno derivado da própria natureza das coisas.

Assim como a doutrina não dedica grande atenção às origens históricas do Procedimento Ordinário, assim também menos ainda se preocupa em rastrear-lhe a evolução, para desvendar a trajetória, rica de ensinamentos, através do direito medieval europeu, de modo que se pudesse recompor a genealogia do conceito de ordinariedade.

Daí porque é comum imaginar-se que o Procedimento Ordinário deva sua natureza, ou sua nota conceitual específica, à circunstância de ser ele um "procedimento plenário", capaz de oportunizar ampla discussão 